\section{Neurodegeneration in zebrafish embryos and adults after cadmium exposure}

\section{Antonio Monaco, Teresa Capriello, Maria C. Grimaldi, Valentina Schiano, Ida Ferrandino}

Department of Biology, University of Naples Federico II, Italy

\begin{abstract}
Cadmium is a biologically non-essential metal. It is also toxic to many organs including the brain. The aim of this study was to analyse the neurodegenerative effects of this metal in embryos and adults of zebrafish exposed to sub-lethal concentrations of cadmium. The study was performed by cytochemical stainings. Six hours post fertilisation (hpf) zebrafish embryos were treated for 24 hours with 9 $\mu \mathrm{M}$ of cadmium and subsequently stained with Acridine orange in whole mount to detect apoptosis in the brain. Adult zebrafish were treated for 16 days with the same concentration of cadmium, and cell death in the brain was detected by FluoroJade B staining at 2, 7 and 16 days of treatment. An increase in cell death was observed only at 16 days of treatment in adults, while an increase in apoptotic events was revealed in the brain of embryos after $24 \mathrm{~h}$ of treatment. This evidence is indicative that cadmium, even at a sub-lethal concentration, induces cell death in the brain of embryos but also in adults of zebrafish in which the phenomenon appears timedependent.
\end{abstract}

\section{Introduction}

Cells react to stress by activating different pathways. Among the reactions cell death can be triggered to eliminate damaged cells. It plays an important role both in its programmed forms and in pathological processes including diseases. Hence the field of cell death has attracted great interest in recent years, especially with respect to studying neurodegenerative diseases. Apoptosis, necrosis and autophagy are distinctive forms of cell death. Different biochemical signals start the process of cell death and action mechanisms depend on the cell's ability to cope with the conditions to which it is exposed. ${ }^{1}$ In the nervous tissue such conditions may include the lack of neu- rotrophic factors, ${ }^{2}$ excitotoxicity, ${ }^{3}$ oxidative stress due to reactive oxygen species (ROS), and alteration of calcium signalling ${ }^{4}$ but also exposure to toxic insults such as metals. ${ }^{5}$

Cadmium $(\mathrm{Cd})$ is a non-essential metal for the human metabolism at any concentration. Unfortunately, it has a high environmental impact and a long biological halflife of $\sim 30$ years with several effects on different organs, inducing apoptosis in vitro and in vivo. ${ }^{6}$ In recent years it has also been indicated as a possible aetiological factor in neurodegenerative diseases. ${ }^{7} \mathrm{Cd}$ significantly increases the levels of lipid peroxidation $^{8}$ and induces accumulation of ROS, which leads to oxidative stress. ${ }^{9} \mathrm{Cd}$ also breaks homeostasis of intracellular free calcium $\left(\mathrm{Ca}^{2+}\right)$, an ion that acts as a signalling mediator in numerous cellular processes including cell proliferation, differentiation and survival/death. Although Cd appears to exert its action through the stimulation of defence processes such as activated metallothionein and chaperones, ${ }^{10}$ numerous studies in vitro and in vivo have shown its ability to induce apoptosis and autophagy in different animal models. ${ }^{6,11,12}$ Indeed, $\mathrm{Cd}$ induces cell death in liver, ${ }^{13}$ in kidney cells, ${ }^{14}$ in muscle ${ }^{15}$ and in the brain of teleost fish ${ }^{16}$ but also in reptiles. ${ }^{17}$

We previously demonstrated that $\mathrm{Cd}$ accumulates in the zebrafish brain with consequent mitochondrial damage and vacuoles observed in this organ under transmission electron microscopy. ${ }^{18}$ Mitochondrial damage is a well-known triggering factor of cell death. Recently we also showed the ability of this metal to damage glial cells, ${ }^{19}$ essential for proper brain homeostasis. In the present work, our aim was therefore to investigate cadmium's ability to induce neurodegeneration both in the brain of zebrafish adult specimens treated for 16 days and in embryos after $24 \mathrm{~h}$ of exposure, in both cases to $9 \mu \mathrm{M}$ of $\mathrm{Cd}$.

\section{Materials and Methods}

\section{Animals}

Specimens of adult zebrafish were housed in well-oxygenated tanks, with a natural photoperiod of $12 \mathrm{~h}: 12 \mathrm{~h}$ light/dark, at a temperature of $28.5^{\circ} \mathrm{C}$ and a $\mathrm{pH}$ of 7.6 . The fish were fed twice a day with TetraMin, and water parameters and quality were checked daily throughout the experiment. $^{20,21}$ All the experiments were performed in accordance with the Guidelines for Animal Experimentation of the Italian Department of Health.
Correspondence: Ida Ferrandino, University of Naples Federico II, Department of Biology, Via Mezzocannone 8, 80134 Napoli, Italy. Tel. +39.081.2535046.

Fax: +39.081 .2535035$

E-mail: ida.ferrandino@unina.it

Key words: Cadmium; cell death; brain; fish; neurodegeneration; zebrafish.

Contributions: AM, study and research design, experiments and stainings performing, data analysis, manuscript drafting; TC, experiments and stainings performing, manuscript writing; MCG, data analysis, manuscript drafting; VS, performing Acridine orange staining on embryos; IF, research design, data analysis, manuscript drafting

Received for publication: 17 July 2017. Accepted for publication: 3 October 2017.

This work is licensed under a Creative Commons Attribution-NonCommercial 4.0 International License (CC BY-NC 4.0).

CC Copyright A. Monaco et al., 2017

Licensee PAGEPress, Italy

European Journal of Histochemistry 2017; 61:2833 doi:10.4081/ejh.2017.2833

\section{Embryo breeding}

Embryos were generated from the above fish, collected with a siphon from the fish tanks and housed in Petri dishes with E3 medium ( $5 \mathrm{mM} \mathrm{NaCl}, 0.17 \mathrm{mM} \mathrm{KCl}$, $\left.0.33 \mathrm{mM} \mathrm{CaCl}{ }_{2} \cdot 2 \mathrm{H}_{2} \mathrm{O}, 0.33 \mathrm{mM} \mathrm{MgSO}_{4}\right)$, kept in a water bath at $28.5^{\circ} \mathrm{C}$. At $6 \mathrm{~h}$ postfertilisation (hpf), the fertilised eggs were selected and then used for experimental procedures.

\section{Embryo treatment}

Healthy embryos at 6 hpf were selected with a Leica Zoom 2000 stereomicroscope at $10 \mathrm{x}$ magnification and were exposed to the metal for $24 \mathrm{~h}$. For the acute treatment in vivo, a stock solution of $50 \mathrm{mM} \mathrm{CdCl}{ }_{2}$ (Carlo Erba, Cornaredo, MI, Italy) was prepared by dissolving $2.51 \mathrm{~g}$ of salt in $250 \mathrm{~mL}$ of breeding solution, and serial dilutions were used to prepare the work solution with $9 \mu \mathrm{M}$ of $\mathrm{Cd}$ concentration. We used a total of 90 treated embryos plus 90 controls simply exposed to breeding solution (resulting from a triplicate treatment). The treatments were conducted in multi-well plates (10 embryos per well) incubated at $28.5^{\circ} \mathrm{C}$.

\section{Acridine orange staining in whole mount}

Apoptosis can be visualised in wholemount of embryos or tissues using dyes 
such as Acridine orange. ${ }^{22}$ Apoptosis was analysed in whole-mount embryos with an exposure to the sub-lethal concentration of $9 \mu \mathrm{M}$, starting from $6 \mathrm{hpf}$ and for $24 \mathrm{~h}$. Control and treated embryos were placed in clean vials. Several rinses were performed with breeding solution to remove the precipitated salts and residues of $\mathrm{Cd}$ in the solution of the treated embryos. The embryos were then exposed to a solution of Acridine orange (Carlo Erba) at a concentration of $100 \mu \mathrm{g} / \mathrm{mL}$ for $1 \mathrm{~h}$, after which several rinses were performed to remove the excess dye. The embryos were then mounted in a drop slide with glycerol and PBS. The images were acquired with a Kontron Electronic Imaging System KS300 (Zeiss, Oberkochen, Germany) by setting the FITC channel. Apoptotic cells were quantified by counting all fluorescent cells in embryo brains using the cell count tool of ImageJ software.

\section{Breeding and treatment of adult fish with cadmium chloride}

Adult specimens of zebrafish from 4 to 10 months of age were used to evaluate $\mathrm{Cd}$ toxicity. The fish were housed and acclimated in tanks equipped with their own oxygenator and thermostat at a temperature of $28.5^{\circ} \mathrm{C}$, with natural photoperiod, and fed with commercial food. The fish were divided into two pools: a control pool with twelve fish exposed to uncontaminated water and one in which twelve fish were exposed to $9 \mu \mathrm{M}$ of $\mathrm{Cd}$ for 16 days. The tanks underwent water and $\mathrm{CdCl}_{2}$ replacement on a daily basis. We assessed the progress of the damage after 2, 7 and 16 days from the beginning of the treatment. Fish were sacrificed by an overdose of MS$222 .{ }^{19,23}$ The brains were rapidly extracted and fixed in Bouin solution for $24 \mathrm{~h}$, subsequently dehydrated and embedded in paraffin.

\section{Histochemical staining by Fluoro- Jade B}

Fluoro-Jade B (AG310 EMD, Millipore, Billerica, MA, USA) is an anionic fluorochrome derived from fluorescein. It is commonly used in neuroscience to reveal degeneration of neurons in the central nervous system resulting from exposure to a variety of neurotoxic insults. ${ }^{24} \mathrm{Six}-\mu \mathrm{m}$ thick brain sections were deparaffinized and rehydrated in absolute ethanol for $3 \mathrm{~min}$, then in $70 \%$ ethanol for $1 \mathrm{~min}$ and finally in distilled water. Subsequently, the sections were incubated for $1 \mathrm{~h}$ at $4^{\circ} \mathrm{C}$ with FluoroJade B, gently shaken in the dark with an orbital shaker. Then the slides were dried overnight at room temperature. The next day the sections were clarified and mounted. The fluorescence images were acquired with a Kontron Electronic Imaging System KS300 (Zeiss) by setting the FITC channel. Analysis of cellular reactivity was performed by comparing the number of fluorescent cells, counted by ImageJ software, in $0.1 \mathrm{~mm}^{2}$ of brain tissue.

\section{Graphics preparation and statistical analysis}

Graphics and statistical analysis were processed by GraphPad Prism 5 (Graph-Pad Software, Inc., La Jolla, CA, USA). Student's $t$-test was used to evaluate the difference of Acridine orange fluorescence between control and treated specimens, while to evaluate the differences of FluoroJade B staining the one-way ANOVA test with Tukey's post-hoc test $(\mathrm{P}=0.05)$ was used. Data are mean $\pm \mathrm{SD}$ : $\mathrm{P}<0.05$ was considered to be statistically significant $(*)$ and $\mathrm{P}<0.001$ very significant $(* * *)$.

\section{Results}

\section{Acridine orange staining}

Control and treated embryos at $30 \mathrm{hpf}$ with a regular phenotype were used for the study of apoptosis in brain of whole mount. An increase in fluorescent cells was observed in treated embryos with respect to controls for all brain areas (Figure $1 \mathrm{a}, \mathrm{b}$ ). From a count of positive cells in the brains of 50 embryos for the experimental group, a 3 -fold increase in the number of apoptotic cells was observed in brains of embryos exposed to Cd compared with the controls
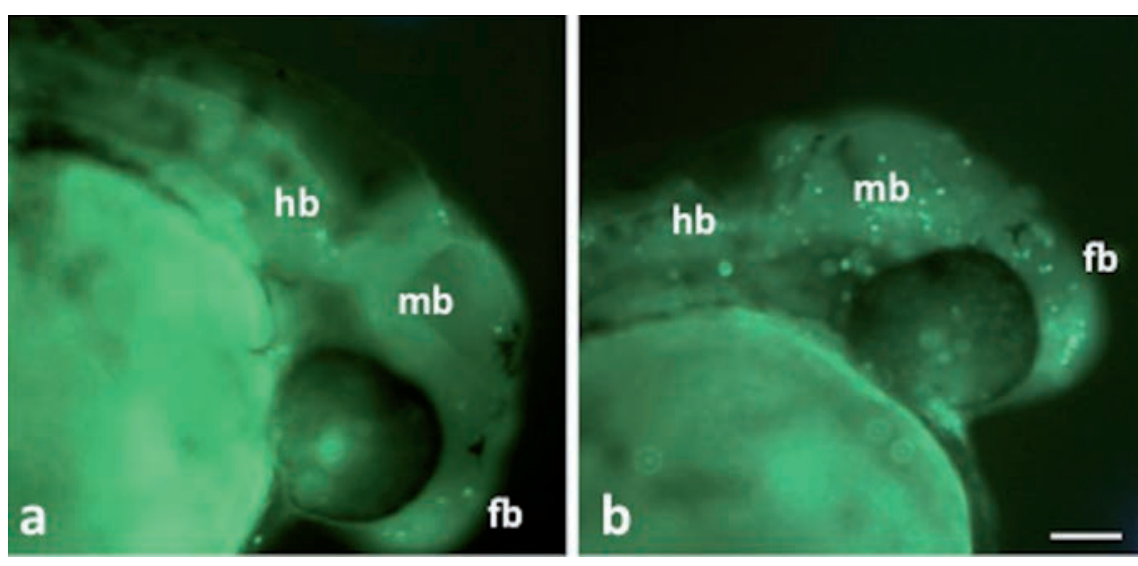

Figure 1. Acridine orange stain in whole-mount zebrafish embryos. a) Control embryos. b) Embryos after 24-hour treatment; note an increase in the number of fluorescent cells in all brain areas. fb, forebrain; mb, midbrain; hb, hindbrain. Scale bar: $75 \mu \mathrm{m}$.
(Figure 2). Interestingly, there was an increase in the number of fluorescent cells in all brain areas.

\section{Fluoro-Jade B staining}

Application of the histochemical technique by Fluoro-Jade $\mathrm{B}$ to detect possible degenerative phenomena was able to identify different fluorescent signals in control and treated adult fish. Few fluorescent signals were revealed in control brains, like those shown in treated fish at 2 and 7 days as reported in the graph for the telencephalon, diencephalon and midbrain (Figure 3). In fish brains at 16 days of treatment a diffused fluorescent signal was revealed especially in the same areas (Figures 3 and 4). In the telencephalon of these fish we observed $55 \pm 10$ positive cells $/ 0.1 \mathrm{~mm}^{2}$ against $11 \pm 5$ positive cells $/ 0.1 \mathrm{~mm}^{2}$ present in the control. The diencephalon appeared to be the area with more positivity than others: Fluoro-Jade B (+) cells in diencephalon numbered $69 \pm 4$ cells $/ 0.1 \mathrm{~mm}^{2}$ vs $10 \pm 3$ cells $/ 0.1 \mathrm{~mm}^{2}$ for the control. In the midbrain we observed $60 \pm 11$ cells $/ 0.1 \mathrm{~mm}^{2}$ vs $13 \pm 6$ cells $/ 0.1 \mathrm{~mm}^{2}$ for the control. The morphology of positive cells appeared variable and probably relative to different cellular types, neurons and also glial cells. Furthermore, fluorescence was particularly present at the level of cell bodies and few nervous processes were stained (Figure 4).

\section{Discussion}

These data confirm the ability of $\mathrm{Cd}$ to damage the brain of adult animals and 
induce alterations in the processes of nervous system development, as was previously observed in other studies. ${ }^{25,19,10}$ In particular, this work shows that $\mathrm{Cd}$ induces death of nervous cells both in embryos and in the encephalon of adult fish. Since the concentration able to induce cytotoxicity is characteristic of contaminated environments, our findings are of ecotoxicological importance. In previous reports, we observed that zebrafish exposure to $\mathrm{Cd}$ at a rate concentration of $1 \mathrm{mg} / \mathrm{L}$ for 16 days caused alterations in the neuroglial component of the zebrafish brain already after 2 days of treatment. ${ }^{19}$ Some of these alterations could be the cause or effect of cell death, as we hypothesised. Consistent with this hypothesis were also observations made by similar experiments on the same model ${ }^{18}$ where alterations were observed in mitochondrial morphology, a principal feature of cell death mechanisms and degeneration processes.

Fluoro-Jade B is widely used in the

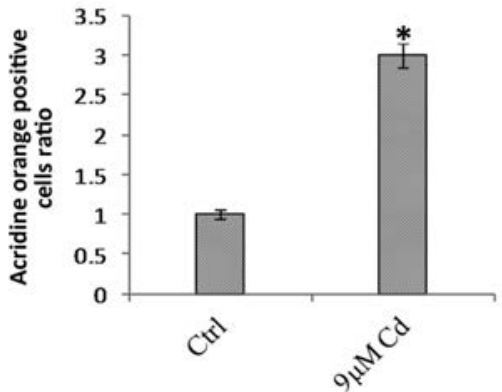

Figure 2. Average of the positive fluorescent cells in the embryos after 24-hour treatment with $9 \mu \mathrm{M}$ of $\mathrm{Cd}$ and in the control embryos by Acridine orange staining in whole-mount. A 3-fold increase in apoptotic cells was observed in the treated embryos compared with the controls. ${ }^{*} \mathbf{P}<\mathbf{0 . 0 5}$.

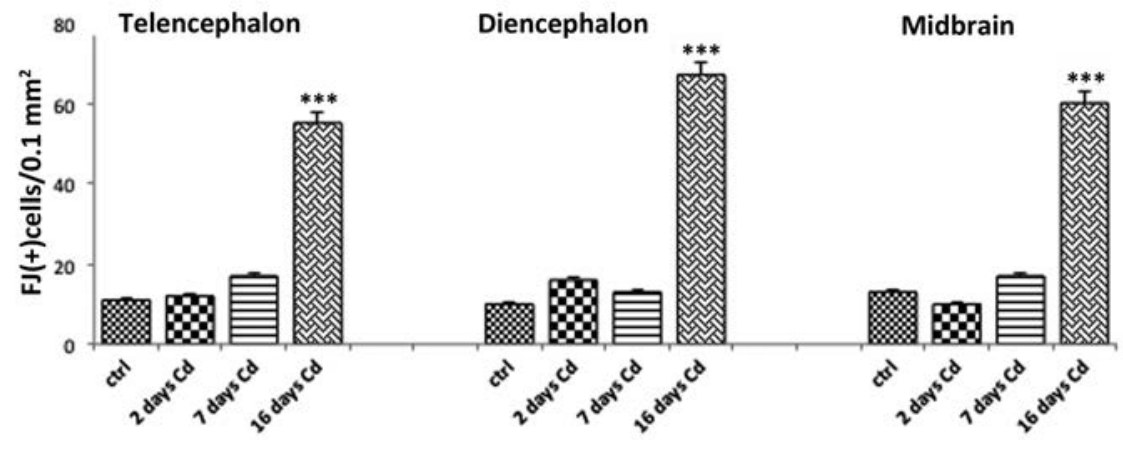

Figure 3. Graphical representation of the mean numbers of Fluoro-Jade B positive cells $/ 0.1 \mathrm{~mm}^{2}$ in the area of the telencephalon, diencephalon and midbrain in zebrafish adults after 2, 7 and 16 days of treatment with $9 \mu \mathrm{M}$ of $\mathrm{Cd}$ and in control fish. Fish treated at 2 and 7 days showed few fluorescent signals similar to those revealed in control brains. A diffused fluorescent signal was particularly revealed at $\mathbf{1 6}$ days of treatment and the diencephalon appeared to be the area with more positivity than the others. *** $\mathbf{P}<\mathbf{0 . 0 0 1}$
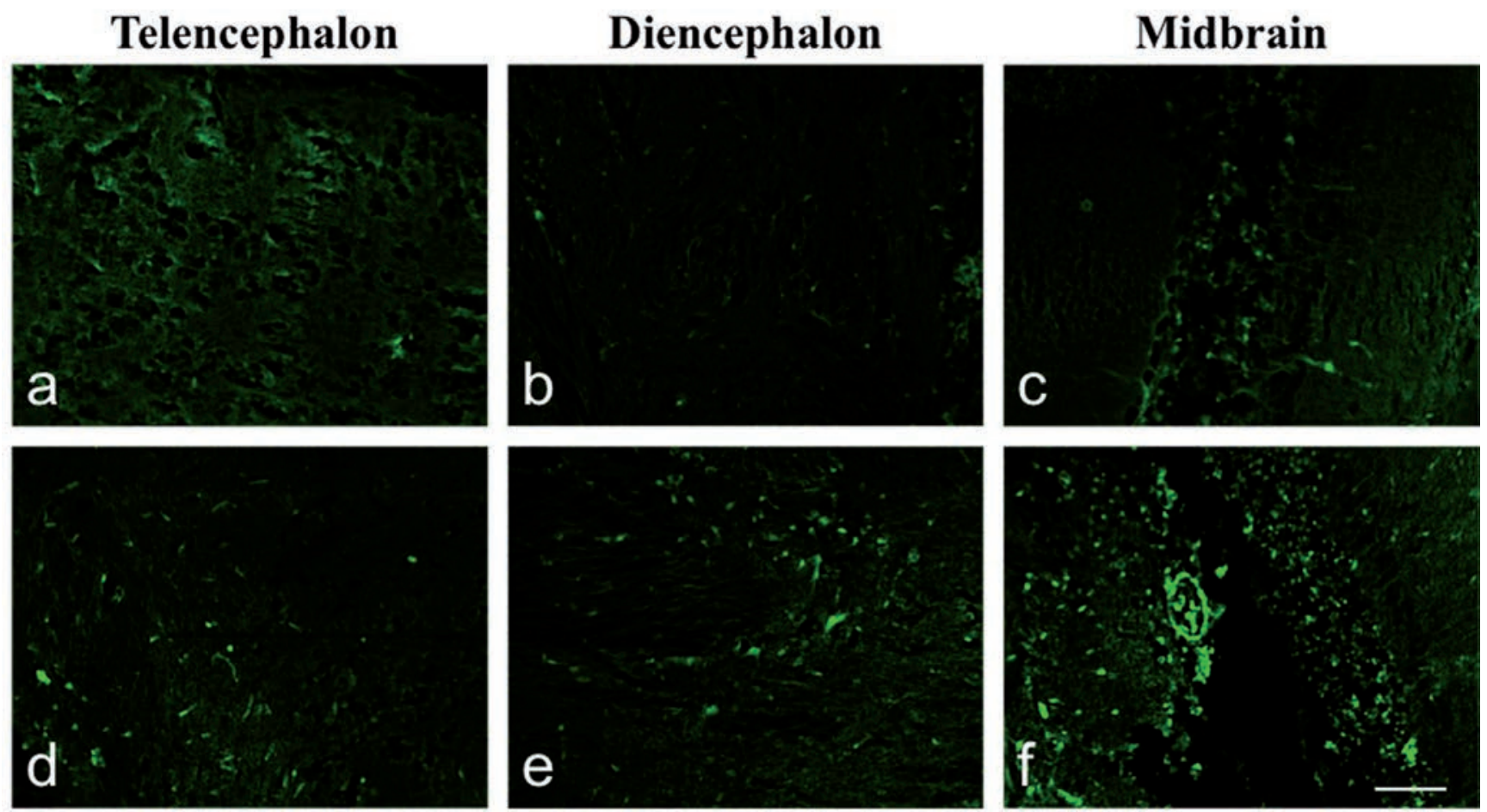

Figure 4. Fluoro-Jade B staining. Sagittal sections: a) telencephalon, b) diencephalon and c) midbrain in control adult fish; d) telencephalon, e) diencephalon and $\mathrm{f}$ ) midbrain of adults after 16 days treated with $9 \mu \mathrm{M}$ of $\mathrm{Cd}$. Note the increase in fluorescence in treated fish compared with the control. Fluorescence was especially present at the level of cell bodies and few nervous processes were stained. Scale bar: $50 \mu \mathrm{m}$. 
field of neuropathology and in animal models of neurological disorders. ${ }^{26}$ This dye is able to evidence degeneration phenomena of nerve cells with a positivity both for neurons and glial cells, ${ }^{27,28}$ considering different types of cell death such as apoptosis and necrosis. ${ }^{29}$ Interestingly, we observed that Fluoro-Jade B positivity significantly increased only after 16 days of exposure to $\mathrm{Cd}$, and the area that showed a marked increased signal was the diencephalon. Other positive cells were also observed in the telencephalon and midbrain. Such observations indicate that cell death also in zebrafish brain cells is a mechanism induced by $\mathrm{Cd}$ and that not all brain areas respond in the same way, perhaps due to the differing sensitivity to $\mathrm{Cd}$ of the various cell populations which are present in the different areas of the zebrafish brain. For example, it has long been known that certain brain cell types, such as dopaminergic neurons, are more susceptible to oxidative stress and environmental stressors and they are affected in several neurological disorders caused by the reduction in functionality of clearance and detoxification processes considering susceptibility to modified and oxidized proteins like alpha synuclein. ${ }^{30}$ However, further investigations are needed to elucidate the cell death processes induced by $\mathrm{Cd}$ in the zebrafish brain since there are known to be several different ways in which this metal can affect brain cells.

\section{References}

1. Fulda S, Gorman AM, Osamu H, Samali A. Cellular stress responses: Cell survival and cell death. Int J Cell Biol 2010;2010:214074.

2. Ichim G, Tauszig-Delamasure S, Mehlen P. Neurotrophins and cell death. Exp Cell Res 2012;318:1221-8.

3. Vaarmann A, Kovac S, Holmström KM, Gandhi S, Abramov AY. Dopamine protects neurons against glutamate-induced excitotoxicity. Cell Death Dis 2013;4: e455.

4. Weber JT. Altered calcium signaling following traumatic brain injury. Front Pharmacol 2012;3:60.

5. Mattson MP. Apoptosis in neurodegenerative disorders. Nat Rev Mol Cell Biol 2000;1:120-9.

6. Habeebu SS, Liu J, Klaassen CD. Cadmium-induced apoptosis in mouse liver. Toxicol Appl Pharmacol 1998;149:203-9.

7. Wang B, Du Y. Cadmium and its neurotoxic effects oxidative medicine and cellular longevity. Oxid Med Cell Longev 2013;2013:898034.

8. Manca D, Ricard AC, Trottier B, Chevalier G. Studies on lipid peroxidation in rat tissues following administration of low and moderate doses of cadmium chloride. Toxicology 1991;67: 303-23.

9. Nair RA, DeGheselle O, Smeets K, Van Kerkhove E, Cuypers A. Cadmiuminduced pathologies: Where is the oxidative balance lost (or not)? Int J Mol Sci 2013;14:6116-43.

10. Simoniello P, Motta CM, Scudiero R, Trinchella F, Filosa S. Cadmiuminduced teratogenicity in lizard embryos: correlation with metallothionein gene expression. Comp Biochem Physiol C Toxicol Pharmacol 2011;153: 119-27.

11. Ferrandino I, Favorito R, Annunziata M, Grimaldi MC. Cadmium induces apoptosis in the pituitary gland of Podarcis sicula. Ann N Y Acad Sci 2009;1163:386-8.

12. Vergilio CdoS S, de Melo EJ. Autophagy, apoptosis and organelle features during cell exposure to cadmium. Biocell 2013;37:45-54.

13. Chen YY, Zhu JY, Chan KM. Effects of cadmium on cell proliferation, apoptosis, and proto-oncogene expression in zebrafish liver cells. Aquat Toxicol 2014;157:196-206.

14. Gao D, Xu Z, Zhang X, Zhu C, Wang Y, Min W. Cadmium triggers kidney cell apoptosis of purse red common carp (Cyprinus carpio) without caspase-8 activation. Dev Comp Immunol 2013;41:728-37.

15. Avallone B, Agnisola C, Cerciello R, Panzuto R, Simoniello P, Cretì P, et al. Structural and functional changes in the zebrafish (Danio rerio) skeletal muscle after cadmium exposure. Cell Biol Toxicol 2015;31:273-83.

16. Chan PK, Cheng SH. Cadmiuminduced ectopic apoptosis in zebrafish embryos. Arch Toxicol 2003;77:69-79.

17. Favorito R, Grimaldi MC, Coppola M, Ferrandino I. Effects of acute cadmium exposure on the pituitary gland of Podarcis sicula. Open Zool J 2010;3:30-6.

18. Favorito R, Chiarelli G, Grimaldi MC, De Bonis S, Lancieri M, Ferrandino I.
Bioaccumulation of cadmium and its cytotoxic effect on zebrafish brain. Chem Ecol 2011;27(Suppl.2):39-46.

19. Monaco A, Grimaldi MC, Ferrandino I. Neuroglial alterations in the zebrafish brain exposed to cadmium chloride. J Appl Toxicol 2016;36:1629-38.

20. Westerfield M. The zebrafish book. A guide for the laboratory use of zebrafish (Danio rerio). 4th ed. Eugene; University of Oregon Press; 2000.

21. Monaco A, Grimaldi MC, Ferrandino I. Aluminium chloride-induced toxicity in zebrafish larvae. J Fish Dis 2017;40: 629-35.

22. Elmore S. Apoptosis: A review of programmed cell death. Toxicol Pathol 2007;35:495-516.

23. Ferrandino I, Grimaldi MC. Ultrastructural study of the pituicytes in the pituitary gland of the teleost Diplodus sargus. Brain Res Bull 2008;75:133-7.

24. Schmued LC, Hopkins KJ. Fluoro-Jade $\mathrm{B}$ : a high affinity fluorescent marker for the localization of neuronal degeneration. Brain Res 2000 25;874:123-30.

25. Favorito R, Monaco A, Grimaldi MC, Ferrandino I. Effects of cadmium on the glial architecture in lizard brain. Eur J Histochem 2017;61:2734.

26. Fritsch B, Qashu F, Figueiredo TH, Aroniadou-Anderjaska V, Rogawski MA, Braga MF. Pathological alterations in GABAergic interneurons and reduced tonic inhibition in the basolateral amygdala during epileptogenesis. Neuroscience 2009;163:415-29.

27. Ehara A, Ueda S. Application of FluoroJade $\mathrm{C}$ in acute and chronic neurodegeneration models: utilities and staining differences. Acta Histochem Cytochem 2009;42:171-9.

28. Damjanac M, Rioux Bilan A, Barrier L, Pontcharraud R, Anne C, Hugon J, et al. Fluoro-Jade B staining as useful tool to identify activated microglia and astrocytes in a mouse transgenic model of Alzheimer's disease. Brain Res 2007; 1128:40-9.

29. Zhou H, Chen L, Gao X, Luo B, Chen J. Moderate traumatic brain injury triggers rapid necrotic death of immature neurons in the hippocampus. J Neuropathol Exp Neurol 2012;71:34859.

30. Dias V, Junn E, Mouradian MM. The role of oxidative stress in Parkinson's disease. J Parkinsons Dis 2013;3:46191. 